\title{
Are CLIL Teachers-to-be Motivated? A Qualitative Study
}

Marta del Pozo Beamud (marta.pozobeamud@uclm.es)

Universidad de Castilla - La Mancha

\begin{abstract}
In recent years, CLIL has gained momentum in Europe and many have been the authors who have analysed the relationship between CLIL and motivation. The vast majority of these studies have focused on learner motivation (Doiz et al., Lasagabaster, Lasagabaster and Sierra, Seikkula-Leino). This study aims to redress that balance by examining teacher motivation, more specifically, the extent to which teachers-in-training of CLIL are motivated. Participants are final-year Primary Education degree students at UCLM $(\mathrm{M}=21.5)$, who completed an open-ended questionnaire examining both intrinsic and extrinsic motivations. Results demonstrated significantly high levels of intrinsic motivation.
\end{abstract}

Keywords: undergraduate students, teacher motivation, CLIL.

\section{¿Están los futuros maestros de CLIL motivados? Un estudio cualitativo}

\section{Resumen}

Durante las últimas décadas, CLIL ha ganado impulso en Europa y muchos han sido los autores que han analizado la relación entre CLIL y la motivación. Sin embargo, la gran mayoría de estos estudios se centran en la motivación del alumno (Doiz et al, Lasagabaster, Lasagabster y Sierra, Seikkula-Leino). Por lo tanto, también se debe prestar atención a la 
motivación de los maestros, de ahí nuestro interés en analizar la motivación de futuros maestros de CLIL. Nuestros participantes son futuros profesores, es decir, estudiantes en su último año de Educación Primaria en la UCLM. Es decir, la edad media es 21,5 años. Para determinar si están motivados (motivación intrínseca/extrínseca), completaron un cuestionario abierto, ya que la naturaleza de esta investigación es cualitativa. En general, los estudiantes muestran una gran cantidad de motivación intrínseca.

Palabras clave: estudiantes universitarios, motivación docente, CLIL.

\section{Introduction}

The main premise of the CLIL approach to language learning is that learners can successfully and effortlessly learn content and language simultaneously (Mehisto et al., Pladevall-Ballester). With its foundation in the Canadian model (one of the first, pioneering models of the CLIL approach within the field of bilingualism), CLIL is now prevalent in Europe with an ever-increasing number of countries and educational establishments adopting the method (Pérez Cañado, "Are Teachers Ready?"). In order to ensure optimal functioning when adopting the CLIL approach, it is appropriate to determine the motivation and satisfaction of all involved. Most studies have focused on the motivation and concerns of students and practicing teachers. This study considers the motivation and concerns of those who will work in this field in the future.

\subsection{Understanding motivation in CLIL}

\subsubsection{Bilingualism and GLIL}

It is evident that bilingual education and more specifically the CLIL approach to second or foreign language learning is now 
widespread in Europe. The number of bilingual schools is growing exponentially on both a national (in this case in Spain) and international level (Moya Guijarro and Ruiz Cordero). This type of education usually takes place in formal contexts (schools, secondary schools, universities, etc.) with the main objective being for the individual to learn two or more languages simultaneously. Since CLIL is a content-based L2 approach, the main premise is that content enhances L2 learning when using a second or foreign language as the vehicular language (Bentley 5, Mehisto et al. 9). According to Christian Abello-Contesse (4), Bilingual Education is an umbrella term "to refer to the regular use of two or more languages for teaching and learning in instructional settings when bilingualism and biliteracy are two of the explicit long-term goals."

Bilingual education translates into different types of educational programmes of a certain duration, in which individuals are instructed in a systematic way, receiving content through two or more vehicular languages. Bilingual Education (B.E.) is "a generic concept that refers to various types of educational programs that provide systematic instruction in two (or more) languages for a prolonged period of time" (Abello-Contesse 4). Within these programmes, CLIL (Content and Language Integrated Learning) has been of particular interest because of its influence over the last decades within the European context (Amengual-Pizarro et al. 6). The rationale of the CLIL approach is that students learn a language (a second or foreign language) other than their mother tongue whilst learning content from other non-linguistic subjects. That is to say, the main interest is not language learning in an isolated manner since the foreign language becomes the means by which content related to natural sciences, social sciences, mathematics, physical education, etc. is learnt (Mehisto et al. 9, Coyle et al. 3).

\subsubsection{Motivation}

Motivation is one of the most studied affective variables involved in the learning of a second or a foreign language. According to Zoltan Dörnyei and Itsván Ottó (64), 
[m]otivation can be defined as the dynamically changing cumulative arousal in a person that initiates, directs, coordinates, amplifies, terminates, and evaluates the cognitive and motor processes whereby initial wishes and desires are selected, prioritised, operationalised and (successfully or unsuccessfully) acted out.

In recent years, there have been many theories regarding this complex psychological dimension. One of the most prominent theories is the Self-determination Theory, a key approach to understanding the function of motivation within the teachinglearning process. This began as a theory within the area of psychology, moving on later to the field of language learning.

The theory proposes a continuum that starts with intrinsic motivation, is followed by extrinsic motivation and terminates in amotivation (Ryan and Deci 16). The most notable difference between extrinsic and intrinsic motivation lies in the fact that the former is linked to the attainment of a specific goal, whilst the latter is related to a genuine interest in a specific activity (Deci and Ryan 233). Furthermore, extrinsic motivation is made up of four different subtypes: external regulation, introjected regulation, identified regulation or regulation through identification and integrated regulation (Ryan and Deci 16-18).

Firstly, external regulation is the least autonomous regulation, since the individual is governed by external demands and contingencies built into society. Thus, what motivates individuals is to obtain rewards or avoid punishment. Secondly, introjected regulation is a partially internalised type of regulation, but it is not part of the individual in an integrated way. Behaviour associated with this regulation includes the avoidance of emotions such as guilt or shame, or even to improve the ego or esteem. Thirdly, identified regulation or regulation through identification is a process of identification which involves the journey from external regulation to true self-regulation. However, on certain occasions these regulations do not fully reflect the thoughts and values of an individual. That is to say, an individual internalises ideas or external values from external 
sources, even though, on occasions, they may not be in line with their own. Fourthly, integrated regulation constitutes the most autonomous form of regulation. In contrast to what happens with the previous regulation, there is complete harmony between the individual and the outside, since this regulation is related to the values, goals and needs of the individual. As can be seen, integrated regulation is very much like intrinsic motivation. However, in the case of integrated regulation, there is a certain goal driving the behaviour and actions of an individual, whilst as previously stated, intrinsic motivation is related to the enjoyment of an activity per se (Ryan and Deci 18). Finally, amotivation is "the absence of any kind of motivation" (Dörnyei and Ushioda 23), and is usually associated with non-acting and passive behaviours (Ryan and Deci 17).

\subsubsection{Teacher motivation}

According to Catherine Sinclair, there is a special type of motivation known as teacher motivation. It can be defined as "[w]hat attracts individuals to teaching, how long they remain in their initial teacher education courses and subsequently the teaching profession, and the extent to which they engage with their courses and the teaching profession" (37).

As previously stated, intrinsic motivation refers to the internal desire to carry out an activity, out of pleasure and interest. In the case of students, they are intrinsically motivated when they are willing to learn a second or a foreign language simply because they enjoy the process. Teachers are intrinsically motivated when they are willing to help their students fulfill their potential, as stated by Eudokia Karavas (61):

Teachers, regardless of sex, teaching experience, position held and location and type of school, have been found to derive their greatest satisfaction and experience a great sense of achievement through working with and for young people and by assisting young people to realise their potential, experience success and grow into responsible adults. 
On the other hand, extrinsic motivation is always associated with the attainment of a specific goal. Students are generally extrinsically motivated when they are willing to learn a foreign language or a second language as a means to an end (i.e., being rewarded, getting a job, promotions, and so forth). In the case of teachers, they are extrinsically motivated when they take into consideration factors such as the community's opinion of them, the level of support by the system to implement curricular changes, available support services, promotion prospects, their status, conditions of service and salary (Farber, Hargreaves, Shann, cited in Karavas 62).

Attention should be paid to the aforementioned factors since they can have a negative effect on teachers' levels of motivation. In Karavas' words, "[t]hese extrinsic, systemically based factors have been identified as powerful dis-satisfiers which detract from or militate from the core business of teaching and which can significantly affect teachers' motivation and their desire to remain in teaching" (62).

\subsubsection{GLIL and motivation}

\subsubsection{GLIL and student motivation}

When investigating student motivation, it is important to be aware of the difficulty in establishing whether levels of motivation are due to the actual type of educational programme students receive, their levels of motivation prior to starting the programme, or both. Another factor to consider is the effect on motivation of those students who experience difficulty following such programmes (Cenoz et al. 14-15).

Nevertheless, studies have shown that students participating in CLIL programmes demonstrate greater motivation and more positive attitudes toward language learning than students learning the more traditional way (EFL) (Doiz et al., Fernández Fontecha and Canga Alonso, Lasagabaster, Lagasabaster and Beloqui, Lasagabaster and Sierra, Pladevall-Ballester, Seikkula-Leino, Sylvén and Thomson).

\subsubsection{GLIL and motivation of in-service teachers}

With regard to practicing teachers, various authors both from Spain and the rest of Europe have applied mostly qualitative approaches and 
analyses when examining these teachers' needs and concerns. Pérez Cañado ("Teacher Training Needs" 285), for example, found that participants (a cohort of students, teachers, teacher trainers and coordinators all across Europe) had good linguistic and cultural competence but lacked basic training in CLIL methodology. She discovered that content teachers had more difficulty than language teachers with regard to interlinguistic and intercultural competence in addition to creating materials, something of great importance (Adams and Cruz-García), and managing resources. Pérez Cañado ("Teacher Training Needs" 285) proved that being proficient in English and/or having spent time abroad also had an impact on linguistic aspects.

In Italy, Infante et al. (162) found that for qualified and practicing teachers, the experience was a positive one. Through their expertise and motivation, these teachers were able to problem-solve assertively while less experienced teachers admitted to needing both more training and access to an online sharing site where their concerns could be expressed with other colleagues in the world of CLIL.

In Spain, Pena Díaz et al. (169-171) conducted a study prior to the implementation of a bilingual programme in Madrid. They found that teachers destined for the programme were highly motivated despite uncertainty and pressure. Fernández and Halbach (17) re-analysed the perception of teachers participating in this programme and concluded that witnessing their students' motivation and reduced anxiety led to their own sense of satisfaction.

These findings are consistent with those of Pena Díaz and Porto Requejo (157) who found that teachers in Madrid had a positive attitude towards the project although the majority pointed to the need for more theoretical knowledge and the need to improve their level of English. These teachers also felt that they would benefit from observing their colleagues. The success of the project was seen to be the result of students and teachers' adaptation.

In Catalonia, Pladevall-Ballester (50-55) also found teachers' experience of CLIL to be positive since they witnessed higher levels of motivation in their students and noticed that students apparently learn in a meaningful way almost without being conscious of the 
process. Practicing teachers also stated that despite students' low level of English, they were able to follow the classes through the use of gestures and mime, etc. In addition, teachers noticed that anxiety levels in their students decreased. There was a need expressed for more support from the institutions, more time for lesson planning and more training.

\subsubsection{CLIL and motivation of pre-service teachers}

As has been previously stated, there are few studies that look at teachers in training. Pérez Cañado ("Are Teachers Ready?" 216) in a European study found that older teachers had a higher level of English and consequently needed less training. Within Europe, teachers in Spain were less knowledgeable when it came to understanding CLIL as a theoretical concept and in terms of their own personal development. Outside Europe, this was also found to be the case with Latin American teachers. In Japan, Kumawaza also found positive attitudes and motivation within the cohort of teachers in training. Kyriacou and Coulthard in the UK, however, obtained inconclusive results since their respondents did not demonstrate much interest in working with children and were neutral regarding self-development. CLIL can therefore be seen to be motivating for students and in-service teachers alike. The aim of this study was to ascertain the nature and degree of motivation in CLIL teachers-to-be regarding their future teaching. We further sought to determine, based on our students' responses, whether they were intrinsically or extrinsically motivated.

\section{Method}

\subsection{Participants}

Participants were university students (total 10, M=21.5). Females outnumbered males by 9:1. Participants were in their last year of a degree in Primary Education at the University of Castilla-La Mancha, in Cuenca, Spain. Nine were Spanish and one Romanian. All were enrolled in a compulsory CLIL methodology subject specialising in English, and as such, CLIL teachers-to-be. The obligatory nature of 
this subject should be taken into consideration when examining the type of motivation experienced by the participants.

It is worth mentioning that both primary and infant education teachers in Spain have to attend university courses along with placements of three months' duration in different schools during their third and their fourth years, respectively. They also decide whether to become English specialists, music specialists, and so on. After graduating, they can choose whether they would like to pursue a career in teaching in the public sector or in the private/semi-private one. If they decide to work in a public school, they have to pass a state exam in which they have to demonstrate both the theoretical and practical knowledge that they have acquired during the previous four years. Those teachers who wish to work in private or semi-private schools are not required to sit the state exam, instead they face a regular job interview with the school board.

With regard to the context of the study, Cuenca is a very small town with just one university. The vast majority of students are from the province itself or from other cities or villages in the same region (Castilla-La Mancha). There are usually more female students than male students, particularly in the Infant Education Degree, this usually being the case on a national level.

\subsection{Instruments and procedures}

Since the nature of this study was qualitative, subjects completed an open-ended questionnaire (10 questions; see Appendix). The questionnaire was based on previous ones (see Dörnyei and Ushioda, Roth et al.). Following the steps of authors such as Roth et al., we decided to base our questionnaire on the Self-determination Theory. The questionnaire was administered by the researcher in class. Before starting, the researcher carefully explained the instructions and students were able to ask questions. When students agreed to participate voluntarily, they had one hour to complete the questionnaire.

In order to interpret the data gathered, qualitative content analysis was carried out. In this type of analysis, themes and main ideas of the 
text are considered the primary content. This content (respondents' answers) is divided into categories, which are the centre of the analysis (Mayring 160-161). In the case of our study, the two categories are extrinsic and intrinsic motivation. Once categories have been outlined and defined, researchers must find examples that illustrate the definition of each category in the informants' narratives (Mayring 163).

\section{Results and discussion}

In this section, the most relevant answers provided by the future teachers are analysed. In the first question ("I would like/wouldn't like to become a CLIL teacher because...") nearly all of the participants (eight) mentioned teaching/educating students as their primary motive for becoming CLIL teachers. Thus, we were able to affirm that almost all of the subjects were intrinsically motivated to become CLIL teachers because they prioritised students and students' well-being over their own personal interests and ambitions. What is more, one subject also said that he/she loved English and derived pleasure from teaching it.

Student \#6: I would like to become a CLIL teacher because I have never learnt at school subjects like language, natural sciences in English and I would like to teach it to know how the students react [...] I like to teach and I like English.

In the second question ("My main motivation(s) for using CLIL methodology in the future is...") six subjects again stated that teaching pupils was their main motivation, whilst the rest (four) were motivated because they considered CLIL to be an innovative method or because they were keen to enhance their teaching practice. In any case, all of them showed again a great amount of intrinsic motivation since they once again put students' needs, interests and well-being first, and wished to improve their teaching.

Student \#7: The innovation because it is something new and different for them, and they can learn new content with a new methodology. In that case, children can pay 
more attention in the classes. From my point of view, CLIL methodology is a tool, which is necessary for children. Because they are going to have the opportunity to learn new content in another language.

In the third question ("What I like most about CLIL is...") all of the participants highlighted the fact that their main interest was the act of teaching students itself and letting pupils be the protagonists of their own learning process. Such answers are consistent with answers to questions 1 and 2, where future teachers agreed on the importance of doing everything possible to facilitate the learning process in an innovative way through projects, etc. We can therefore again conclude that participants were intrinsically motivated.

Student \#1: In CLIL, students should be the absolute protagonists.

In the fourth question ("Teaching CLIL will mean social prestige, which I find/do not find particularly relevant because...") almost half of the participants were keen to become CLIL teachers because of social prestige, thus implying extrinsic motivation (integrated regulation). Since the remaining participants did not prioritise social prestige as a reason for pursuing a career in teaching, they would appear to be intrinsically motivated.

Student \#4: The real objective is that pupils can learn.

In the fifth question ("I find/do not find CLIL teaching rewarding because...") seven participants claimed that teaching students was most rewarding for them, whereas the rest of the participants found it satisfying for personal reasons. Regardless, all of them find teaching rewarding either because they wished to have a positive impact on their students or simply because they wanted to enhance their practice, thus favourably influencing the well-being of their students.

Student \#7: CLIL teaching can open my mind about all the things that I don't know anything about.

In the sixth question ("I consider/do not consider teaching values 
and educating people to be a core aspect of teaching CLIL since...") all the teachers-to-be considered values to be a matter of great importance. Their primary role was seen to be to educate their pupils and teach them solid values. One could therefore affirm that they are all intrinsically motivated since their main preoccupation is to help their students become better citizens of the world.

Student \#3: As teachers we have to educate people, not only give them contents.

Student \#5: I think that teaching values should be a basic aspect of my teaching.

In the seventh question ("I believe/do not believe that teaching CLIL will be positive for my professional career since...") all participants were aware of the positive aspects of CLIL teaching, all picturing themselves working in bilingual schools in the future, the prospect of which they believe will be enriching and rewarding. In this case, their responses clearly showed a tendency for extrinsic motivation (integrated regulation) since it was their prospective careers which were the focus of concern.

Student \#7: In the future all the schools would be bilingual, so it is a big opportunity to work in one of them.

One of the participants also highlighted the importance of dedication to being a teacher and of being able to transmit this to students. In this particular case, this teacher-to-be was also intrinsically motivated due to the fact that, apart from being concerned about his/her future career in teaching, he/she is also keen to make an impact on his/her students' lives.

In the eighth question ("If I become a CLIL teacher, I will look for new methodologies/ways of teaching because...") all the participants strongly believed that new methodologies are most beneficial for students. Two of them also expressed an internal desire to improve as teachers. These teachers-to-be can be seen to be intrinsically motivated since they are willing to use new 
methodologies in order to have a positive impact on their students' needs, interests, motivation, etc., and they are also willing to enhance their everyday practice.

Student \#3: Our objective is to improve the teaching in our country and improve ourselves as teachers.

In the ninth question ("If I ever become a CLIL teacher, I would/would not like to make an effort to please my students' parents") six of the subjects agreed with this statement, whereas four of them placed more importance on children and their well-being. What is more, one teacher-to-be claimed that teachers should know better than parents what is best for children when it comes to education and students' needs. Six subjects were extrinsically motivated (integrated) because their practice would be guided/influenced by external factors, in this case, parents. In contrast, four teachers could be seen to be intrinsically motivated due to the fact that their practices would not be affected by opinions and judgements of their pupils' parents.

Student \#4: I think that it isn't important because the principal objective is that the students could learn in a good way and if it is not pleasant for the parents, it isn't important for me. But I think is better to have a good relationship with their parents too.

As regards the last question ("Teaching CLIL will/will not be a dream come true due to the fact that..."), for all the subjects teaching CLIL would indeed be a dream come true. Nonetheless, for two subjects that dream is somehow something more general, rather than personal. Nonetheless, we can once again affirm that the total number of the teachers-to-be were intrinsically motivated because they dream about becoming successful CLIL teachers one day.

Student \#3: I love teaching and I love English. In my opinion to be a CLIL teacher will be my perfect profession because I will be able to create new projects about English and communication, and I will be able to see good results in my children, which makes me happy. 
Having presented the results, we can confirm that our participants (CLIL teachers-to-be) showed a great amount of intrinsic motivation in nearly all the responses to questions, except for questions 4,7 , and 9 , where extrinsic motivation (internal regulation) is present. In other words, participants find factors such as social prestige, professional development or parents' endorsement pivotal. These results are not consistent with those by Karavas (64) in Greece, whose participants considered extrinsic factors such as salary, promotion or status to be of lesser importance when it comes to choosing a career in teaching. This may be due to the compulsory nature of the CLIL module.

On the other hand, teaching and educating students appear to be teachers' main priorities along with enhancing their teaching practice by being able to constantly update their knowledge, methodologies, and so on. Our participants were willing to prioritise their students' needs, interests and motivations over their own personal needs. Such results are in line with those found by Kumazawa (50) in Japan, who discovered that some of her participants (pre-service teachers) were passionate about the educational process. Our results are also in accordance with those presented by Karavas (64) in that she discovered that participants in her study were intrinsically motivated since they considered reasons like working with young people/helping them/changing their lives or the interest/love for the subject they teach the most important ones. However, it should be noted that, in a similar study carried out by Kyriacou and Coulthard $(119,122)$ in the UK, working with children was not a priority for their participants (undergraduate students). Furthermore, our students demonstrated a wish to be constantly learning; self-development is crucial for them and this would certainly have a positive repercussion for their students. Neither are these results very much in line with those obtained by Kyriacou and Coulthard $(119,124)$ in the UK, who stated that their participants were very neutral about the importance of selfdevelopment when considering a career as a school teacher. It should be noted, however, that the structure of teacher training can vary between different countries; students might have to take more general degrees and specialise in education in postgraduate courses. This, of course, would have an impact on the pre-service teachers' motivation.

We can affirm that the results found are consistent with those of Fernández and Halbach, Infante et al., Pena Díaz et al., Pena Díaz 
and Porto Requejo, Pérez Cañado, and Pladevall-Ballester, to name but a few. These studies were carried out with in-service teachers in Europe and in Spain and not with pre-service teachers, but the results could be extrapolated to our sample. All the aforementioned authors agree that their participants had a very high degree of motivation. However, it should be noted that in some regions CLIL students are selected based on external factors such as good grades and in some cases they are not in a position to choose whether they become part of the programme or not. Despite having important needs and concerns, they are practitioners who strive every day to improve and they feel great pride and personal satisfaction when witnessing how their pupils succeed in the learning of content and language at the same time, despite the difficulties (their poor level of English, content or both, etc.).

\section{Conclusion}

Once the results were analysed by using the categorisation system in which two main categories were outlined (extrinsic and intrinsic motivation) and having found definitions of both types of motivation in the informants' responses, we proceed to present the pertinent conclusions.

Pre-service teachers are driven primarily by intrinsic motives in addition to some extrinsic motives in their everyday practice. They strive to make a positive impact on their students' lives. As we have seen, they also value extrinsic aspects such as social status, parental recognition, etc. In Karavas' words,

[t]eachers are aware of instability and unpredictability that characterises their profession, they choose to enter teaching on the basis of altruistic and intrinsic reasons, motivated by their love of the subject, their desire to help children realise their potential and driven by their firm belief that they can make a difference in students' lives. They generally seem satisfied with various aspects of their work such as the recognition they receive for their efforts from students primarily and from parents, their 
benefits and working hours and their status as EFL teachers in school and in society. (71)

Notwithstanding, with these motivations also come desires and needs that should be heeded by the institutions. Our study highlights the importance of and need for permanent training for all CLIL 'actors': in-service, pre-service, etc., along with material and personal resources. It is clear that those who are striving to make a success of CLIL need to feel supported by their colleagues and the local/national institutions.

These results have certain pedagogical implications given that participants generally show high levels of intrinsic motivation. Firstly, it would be advisable for them to try to maintain such levels of motivation during their future practice, and this is not necessarily an easy task. As authors like Han and Yin (3) and Kumazawa (49) state, teachers-to-be are full of ideals, passion and altruism, factors that tend to decrease once they start teaching and face reality. Therefore, such ideals are quite often most unrealistic, and this can affect teacher motivation negatively (Kumazawa 53). Secondly, if they are motivated, they can surely transmit their motivation to their own students. Moreover, one could also look for connections between the teachers' style(s) and the motivation of their students, as Noels did (125). In fact, this relationship is bilateral since teachers are also very much affected by their students' motivation. Teachers around the globe are known for being enthusiastic if they feel their students are enthusiastic too, and for feeling demotivated if their students are not very motivated (Karavas 61). However, according to Han and Yin (14), "[a]mong the examined relationships between teacher motivation and teaching behaviours or styles, and student motivation, the linkage is rather uncertain due to the research design and paucity in existing literature." Such relationships should be further explored through new studies and approaches. It is therefore possible to extrapolate that if future teachers are motivated, and given that they are particularly keen to learn about CLIL methodology, this will necessarily have a positive effect on their training and ultimately their careers as teachers.

Regarding future research, we would like to carry out the same study with a larger sample in order to obtain a bigger picture since we 
are aware of the limited number of participants. What is more, it could be interesting to analyse the results from a gender perspective in order to discover whether female teachers are more motivated than male teachers, as is often the case among students (Baker and MacIntyre, Dörnyei et al.). Finally, it would be advisable to replicate the study at other universities (nationwide and internationally) to discover whether there are regional/national/international differences and, if so, why, since, as stated in the introduction section, there are few studies examining future CLIL teachers' motivation.

\section{Works cited}

Abello-Contesse, Christian. "Bilingual and Multilingual Education: An Overview of the Field." Bilingual and Multilingual Education in the 21st Century: Building on Experience, edited by Christian Abello-Contesse, Paul M. Chandler, María Dolores LópezJiménez and Rubén Chacón-Beltrán, Multilingual Matters, 2013, pp. 3-23.

Adams, Heather, and Laura Cruz-García. "Use of Teaching Materials in Foreign Language Classes for Trainee Translators in Spain." Babel-AFIAL: Aspectos de filoloxía inglesa e alemá, no. 26, 2017, pp. 101-118.

Amengual-Pizarro, Marian, Jesús García-Laborda, and Cristina CalleMartínez. "Methodological Approaches in the Didactic Second Language Context." Verbeia, no. 1, 2017, pp. 5-15.

Baker, Susan C., and Peter D. MacIntyre. "The Role of Gender and Immersion in Communication and Second Language Orientations." Language Learning, vol. 50, no 2, June 2000, pp. 311-341.

Bentley, K. The TKT Course: CLIL Module. Cambridge University Press, 2010.

Cenoz, Jasone, Fred Genesee, and Durk Gorter. "Critical Analysis of CLIL: Taking Stock and Looking Forward." Applied Linguistics, vol. 35, no. 3, 2014, pp. 243-262.

Coyle, Do, Philip Hood, and David Marsh. Content and Language Integrated Learning. Cambridge University Press, 2010.

Deci, Edward L., and Richard M. Ryan. "The 'What' and 'Why' of Goal Pursuits: Human Needs and the Self-Determination of Behavior.” Psychological Inquiry, vol. 11, no. 4, 2000, pp. 227-268. 
Doiz, Aintzane, David Lasagabaster, and Juan Manuel Sierra. "CLIL and Motivation: The Effect of Individual and Contextual Variables." The Language Learning Journal, vol. 42, no. 2, March 2014, pp.209-224.

Dörnyei, Zoltán, Kata Csizér, and Nóra Németh. Motivation, Language Attitudes and Globalisation: A Hungarian Perspective. Multilingual Matters, 2006.

Dörnyei, Zoltán, and Itsván Ottó, "Motivation in Action: A Process Model of L2 Motivation." Working Papers in Applied Linguistics, vol. 4, 1998, pp. 44-69.

Dörnyei Zoltán, and Emma Ushioda. Teaching and Researching Motivation (2nd edition). Pearson, 2011.

Farber, Barry A. "Stress and Burnout: Implications for Teacher Motivation." Paper presented at the Annual Meeting of the American Educational Research Association, New York, March 1982.

Fernández, Raquel, and Ana Halbach. "Analysing the Situation of Teachers in the CAM Bilingual Project after Four Years of Implementation." Content and Foreign Language Integrated Learning: Contributions to Multilingualism in European Contexts. Peter Lang, 2010.

Fernández Fontecha, Almudena, and Andrés Canga Alonso. "A Preliminary Study on Motivation and Gender in CLIL and Non-CLIL Types of Instruction." International Journal of English Studies, vol, 14, n. 1, 2014, pp. 21-36.

Han, Jiying, and Hongbiao Yin. "Teacher Motivation: Definition, Research Development and Implications for Teachers." Cogent Education, vol. 3, no. 1, August 2016, www.tandfonline.com/ doi/full/10.1080/2331186X.2016.1217819.

Hargreaves, Andy. Changing Teachers, Changing Times: Teachers' Work and Culture in the Postmodern Age. Teachers College Press, 1994.

Infante, Debora, Guido Benvenuto, and Emilio Lastrucci. "The Effects of CLIL from the Perspective of Experienced Teachers." CLIL Practice: Perspectives from the Field, 2009, pp. 156-163.

Karavas, Evdokia. "How Satisfied are Greek EFL Teachers with their Work? Investigating the Motivation and Job Satisfaction Levels of Greek EFL Teachers." Porta Linguarum, no. 4, June 2010, pp. 59-78. 
Kumazawa, Masaño. "Gaps Too Large: Four Novice EFL Teachers' Self-concept and Motivation." Teaching and Teacher Education, no. 33, July 2013, pp. 45-55.

Kyriacou, Chris, and Melissa Coulthard. "Undergraduates' Views of Teaching as a Career Choice." Journal of Education for Teaching, vol. 26, no. 2, August 2010, pp. 117-126.

Lasagabaster, David. "English Achievement and Student Motivation in CLIL and EFL Settings." Innovation in Language Learning and Teaching, vol. 5, no. 1, 2011, pp. 3-18.

Lasagabaster, David, and Raquel Beloqui. "The Impact of Type of Approach (CLIL versus EFL) and Methodology (Book-based versus Project Work) on Motivation." Porta Linguarum, no. 23, January 2015, pp. 41-57.

Lasagabaster, David, and Juan Manuel Sierra, "Language Attitudes in CLIL and Traditional EFL Classes." International CLIL Research Journal, vol. 1, no. 2, 2009, pp. 4-17.

Mayring, Philipp. "Qualitative Content Analysis." Forum Qualitative Sozialforschung, vol. 1, no. 2, June 2000, www.qualitativeresearch.net/index.php/fqs/article/view/ 1089/2385.

Mehisto, Peeter, María Jesús Frigols, and David Marsh. Uncovering CLIL: Content and Language Integrated Learning in Bilingual and Multilingual Education. Macmillan Education, 2008.

Moya Guijarro, Arsenio Jesús, and Begoña Ruiz Cordero. "Un estudio sobre la diferencia de nivel de competencia lingüística entre alumnos pertenecientes a centros bilingües y no bilingües en la comunidad autónoma de Castilla-La Mancha (España).” Estudios filológicos, no. 62, 2018.

Noels, Kimberly. A. "Learning Spanish as a Second Language: Learners' Orientations and Perceptions of their Teachers' Communication Style.” Language Learning, vol. 51, no. 1, June 2008, pp. 107-144.

Pena Díaz, Carmen, Raquel Fernández Fernández, Antonio García Gómez, and Ana María Halbach. "La implantación de proyectos educativos bilingües en la Comunidad de Madrid: Las expectativas del profesorado antes de iniciar el proyecto.” Porta Linguarum, no. 3, January 2005, pp. 161-173.

Pena Díaz, Carmen, and María Dolores Porto Requejo. "Teacher Beliefs in a CLIL Education Project." Porta Linguarum, no. 10, June 2008, pp. 151-161. 
Pérez Cañado, María Luisa. "Teacher Training Needs for Bilingual Education: In-service Teacher Perceptions." International Journal of Bilingual Education and Bilingualism, vol. 19, no. 3, December 2014, pp. 266-295.

Pérez Cañado, María Luisa. "Are Teachers Ready for CLIL? Evidence from a European Study." European Journal of Teacher Education, vol. 39, no. 2, January 2016, pp. 202-221.

Pladevall-Ballester, Elisabet. "Exploring Primary School CLIL Perceptions in Catalonia: Students', Teachers' and Parents' Opinions and Expectations." International Journal of Bilingual Education and Bilingualism, vol. 18, no. 1, 2014, pp. 45-59.

Roth, Guy, Avi Assor, Yaniv Kanat-Maymon, and Haya Kaplan. "Autonomous Motivation for Teaching: How Self-determined Teaching may Lead to Self-determined Learning." Journal of Educational Psychology, vol. 99, no. 4, 2007, pp. 761-774.

Ryan, Richard M., and Edward L. Deci. "An Overview of Selfdetermination Theory: An Organismic Dialectical Perspective." Handbook of Self-determination Research, edited by Edward L. Deci and Richard M. Ryan, The University of Rochester, 2002, pp. 3-33.

Seikkula-Leino, Jaana. "CLIL Learning: Achievement Levels and Affective Factors." Language and Education, vol. 21, no. 4, 2007, pp. 328-341.

Shann, Mary H. "Personal Commitment and Satisfaction among Teachers in Urban Middle Schools." The Journal of Educational Research, vol. 92, no. 2, 1998, pp. 67-73.

Sinclair, Catherine. "Initial and Changing Student Teacher Motivation and Commitment to Teaching." Asia $\square$ Pacific Journal of Teacher Education, vol. 36, no. 2, 2008, pp. 79-104.

Sylvén, Liss Kerstin, and Amy S. Thompson. "Language Learning Motivation and CLIL: Is There a Connection?" Journal of Immersion and Content-Based Language Education, vol. 3, no. 1, 2015, pp. 28-50. 


\section{APPENDIX: THE QUESTIONNAIRE}

\section{FL MOTIVATION}

Answer the following questions.

Age:

Gender: M / F

1. I would like/wouldn't like to become a CLIL teacher because ...

2. My main motivation(s) for using CLIL methodology in the future is...

3. What I like most about CLIL is...

4. Teaching CLIL will mean social prestige, which I find/do not find particularly relevant because...

5. I find/do not find CLIL teaching rewarding because...

6. I consider/do not consider teaching values and educating people to be a core aspect of teaching CLIL since...

7. I believe/do not believe that teaching CLIL will be positive for my professional career since...

8. If I become a CLIL teacher, I will look for new methodologies/ways of teaching because...

9. If I ever become a CLIL teacher, I would/would not like to make an effort to please my students' parents.

10. Teaching CLIL will/will not be a dream come true due to the fact that... 